\title{
Physical Properties of Straw Bales as a Construction Material: A Review
}

\author{
Stefano Cascone ${ }^{1, * \mathbb{C}}$, Renata Rapisarda ${ }^{1}$ and Dario Cascone ${ }^{2}$ \\ 1 Department of Civil Engineering and Architecture, University of Catania, Via Santa Sofia 64, 95123 Catania, \\ Italy; renata.rapisarda.91@gmail.com \\ 2 Faculty of Engineering and Architecture, University of Enna Kore, Via delle Olimpiadi, 94100 Enna, Italy; \\ dario.cascone@unikore.it \\ * Correspondence: stefano.cascone@unict.it
}

Received: 24 May 2019; Accepted: 17 June 2019; Published: 19 June 2019

check for updates

\begin{abstract}
Straw bale buildings provide significant benefits in terms of costs, human health, and environmental sustainability. Several studies in different regions have underlined the remarkable properties of straw bales as insulating and construction material; however, to the authors' knowledge, there are no reviews published on this topic. The main objective of this paper is to provide a better understanding of straw bale systems, focusing on durability and thermal and acoustic insulation properties. To this end, previous tests and studies on straw bale buildings around the world were reviewed, comparing their results, assessing where research currently stands, and identifying the aspects that need to be further investigated. Results from previous tests have highlighted their ability to achieve excellent living comfort and encouraged their use. Guidelines for the characteristics to be achieved during the baling process are now required. Combining straw bale walls with a render or any type of high-density layer can improve both the thermal and acoustic properties of straw bale constructions. Finally, a quantitative assessment of the most significant properties, such as thermal resistance and acoustic insulation, is necessary to reduce the gap between straw bales and traditional building materials.
\end{abstract}

Keywords: environmental sustainability; moisture content; thermal performance; acoustic insulation; agricultural waste

\section{Introduction}

About $90 \%$ of the materials used for thermo-acoustic insulation are synthetic products, whose manufacturing processes require high amounts of nonrenewable resources and generate a range of greenhouse gas emissions [1]. This percentage can be decreased by turning to natural materials, especially by reusing byproducts of production, such as straw [2]. Bio-based materials are one of the most sustainable choices when it comes to $\mathrm{CO}_{2}$ emissions, since they act as a carbon sink throughout the building's life [3].

Straw bale buildings have been primarily used for housing and for community centers in rural areas. Straw houses have existed since baling machines were introduced, going back to the late $1800 \mathrm{~s}$ when American settlers used straw bales as blocks to build temporary shelters in agricultural fields while harvesting crops.

Straw is a coproduct of cereal production and has no value as animal feed, although it can be used as bedding or ploughed back into the ground as a soil conditioner. A report published by the Food and Agriculture Organization (FAO) of the United Nations estimated that each year, roughly 800 to 1000 million tons per year of rice straw is produced, with about 600 to 800 million tons per year produced in Asia [4]. Therefore, it is cheap and easy to access in most countries [5]. However, when straw is dry, it 
does not have any nutritional value for animals and it is mostly baled in rectangular or circular shapes or disposed of by being buried or burned into the soil, causing environmental problems due to gas release in the atmosphere [6].

Straw bales can provide significant benefits in terms of costs, human health, and environmental sustainability [7]. Several studies in different regions have underlined the remarkable properties of straw bales as insulating and construction material, highlighting their ability to achieve excellent living comfort and encouraging their use, even though straw bale constructions do not have a significant place in current building practices [8-10]. Due to their advantages, straw bales were mainly utilized in traditional rural buildings to improve environmental sustainability. Barbaresi et al. [11] tested the effectiveness of straw bales as retrofit interventions for thermal behavior improvement in unconditioned above-ground farm buildings, referring to wine-ageing requirements. Whitman [12] presented measurements of dry bulb temperatures and relative humidity, both in physical test chambers and Chilean straw bale homes. The results showed that straw bales provided a viable solution for comfortable, energy efficient rural dwellings in Chile's Central Valley.

In order to perform best as a construction material, straw bales should be dry, with a moisture content below $20 \%$ (calculated as a percentage of the total weight of the bale) [13], free from seeds that can attract rodents, and compact, in order to remain stiff when loads are applied.

However, since straw bale performance is influenced by several factors, researchers and designers have found it difficult to define which parameters should be used in both experimental and simulation studies. In fact, characteristics of straw vary from one specimen to another and they are not applicable in all circumstances. In 2006, King [14] published a book covering the collective wisdom and experience of the most senior and respected figures in the field of straw bale construction. The information included in this book are a guide to design and build with straw bales. However, many research papers have been published since 2006. Concerning the scientific literature, only Yin et al. [15] have reviewed previous studies on the sorption property of wheat and rice straw and the microstructure that affects the sorption property. Therefore, to the authors' knowledge, there are no review papers published on straw bale buildings summarizing the results obtained by previous research on the durability and insulation performance. In addition, it is necessary to rectify the lack of guidelines and regulations for straw bale practices by providing a baseline to guide the approach to straw bale construction.

The main objective of this paper is to provide a better understanding of straw bale systems, focusing on durability and thermal and acoustic insulation properties, which are considered primary topics when approaching straw bale constructions. To this end, previous tests and studies on straw bale buildings around the world were reviewed, comparing their results, assessing where research currently stands, and identifying the aspects that need to be further investigated. However, due to the high number of studies carried out on straw bale buildings, this review is focused on the research that expressly evaluates, experimentally or analytically, the durability and the thermal and acoustic insulation properties. Therefore, all studies examining other critical topics, including structural and environmental performance and fire resistance, are outside the scope of this study.

First, the characteristics of straw as a building material are described. Then, moisture content assessment is discussed. The second part of this paper analyzes the test results from both laboratory and in situ testing that have been carried out in order to assess how straw bale buildings perform and the implications of using straw bales as a construction material.

\section{Construction Techniques}

The main construction techniques for straw bale buildings are load bearing and infill wall systems (Figure 1) [16]. Load bearing panels, consisting of stacked straw bales and plaster skins, exploit the structural capacity of the plaster/straw composite. Since the structural resistance of the straw is lower than plaster, the majority of load is carried by the plaster. The render plays a significant structural role, increasing resistance and improving stiffness (limiting movement) as well as protecting the straw from decay and enhancing fire resistance. Vardy and MacDougall [17] illustrated how the strength of the 
plaster, the thickness of the plaster, and the orientation of the bale itself can affect the strength of the plastered bale. The results demonstrated that although the plaster strength does affect the strength of the plastered bale, it does not have as significant an impact as the plaster thickness.

In post and beam systems with straw infill, loads are supported by the frame structure and straw bales provide thermal and acoustic insulation. Even in post-and-beam systems, the plaster plays a secondary structural role in resisting, for example, wind pressures or helping to provide lateral resistance. However, plastering bales is labor intensive and costly. Therefore, some researchers have assessed different materials that are suitable to replace the plaster. Beaudry and MacDougall [18] developed dry bale wall panels consisting of a perimeter timber frame, recycled wood sheathing on both sides, and wheat straw bale infill. Gravity and transverse load testing were performed. The authors concluded that these panels exceeded the structural capacities of conventional structural insulated wall.

In load bearing systems, the roof is built last; therefore, if the construction process does not happen quickly, the straw is more vulnerable to water damage. However, in post and beam systems, the frame is built first and the straw insulation is put into place afterwards [19].

The straw bales can be placed either flat or on edge in straw bale buildings. The laid-flat construction is normally applied in load-bearing construction with bale density no less than $130 \mathrm{~kg} / \mathrm{m}^{3}$ [14]. Laid-on-edge construction is always applied in nonload-bearing constructions and curved walls [14]. There is no strict bale density for nonload-bearing straw bale buildings and the densities are normally greater than $70 \mathrm{~kg} / \mathrm{m}^{3}$ in the industry.

Yin et al. [16] reviewed the types of materials that are applied to exterior and interior surfaces. There are four plaster materials which can be used in render layers of straw bale construction: cement, lime, clay, and gypsum. Straw bale walls should normally be finished with a vapor-permeable render (such as lime) both internally and externally. The render layer should be breathable enough to allow trapped moisture to escape from the straw bales. The use of cement render should be cautious, as the presence of cement in the render will reduce its permeability and could lead to moisture becoming trapped within the bales.

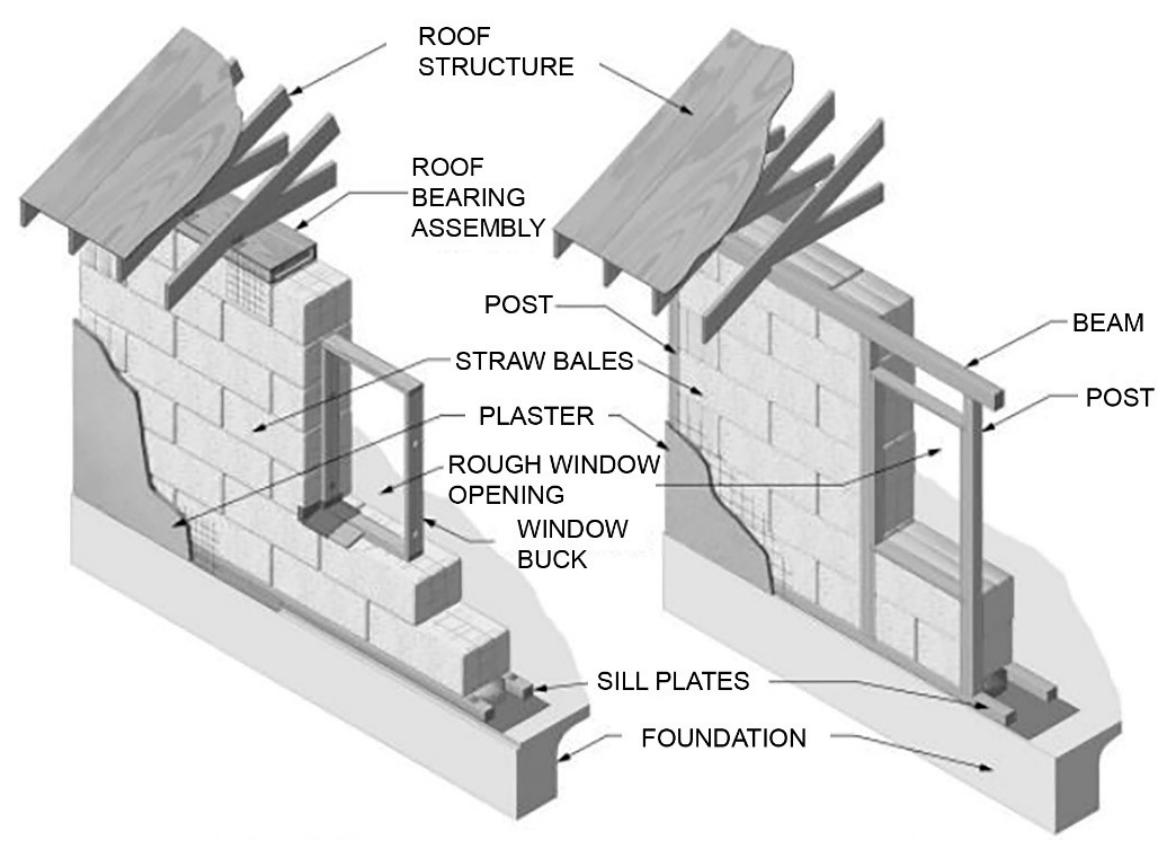

Figure 1. Load bearing (left) and post and beam with straw bale infill (right) [20]. 


\section{Fire Resistance and Environmental Performance}

In this section, the main characteristics of straw bales are described, not in terms of durability and insulation that are addressed in central part of this paper, but in terms of fire resistance and sustainability, in order to provide an overview of straw bale performance.

Fire resistance is an unexpected property of straw bales because, when loose, straw is highly flammable, while when baled, straw can provide fire resistance comparable to traditional construction materials. Apte et al. [21] tested the fire resistance of straw bales and reported that a compacted bale, with a $4 \mathrm{~cm}$ of plaster on all sides, survived under $29 \mathrm{~kW} / \mathrm{m}^{2}$ heat flux for $10 \mathrm{~min}$, showing no severe render cracking or straw ignition. The fire resistance increased thanks to the plaster layer, since it provided an insulating barrier against the heat source and oxygen transfer from the atmosphere into the straw. Marković and Milić [22] demonstrated that straw-filled structures show surprisingly good resistance to fire load in terms of the time needed to collapse the structure from the moment of fire. The wall was exposed to the fire load for $85 \mathrm{~min}$, with a temperature of $800{ }^{\circ} \mathrm{C}$ on the side affected by the fire. During the test, there was no collapse of the structure or a disturbance of the bearing capacity. Teslík et al. [23] reported the first step of research on the reaction to fire. The ignitability fire test using a small-time attack flame showed that crushed straw placed in the structure does not heavily contribute to the spread of fire.

Straw is a natural organic material and its environmental benefits involve reductions in waste disposal and easy accessibility all over the world, with no requirement to transport it over long distances from where the straw is available. However, there are many other locations where straw needs to be transported long distances and therefore may not be a good choice. Nozdrovicky et al. [24] evaluated the technical and economic effects of straw processing, including straw baling, transport, and handling. The results showed that transport distance affected the fuel consumption during straw harvest, baling, and bales' transport. These analyses are fundamental to assess the environmental performance of straw bales. Gonzalez [25] reported that the embodied energy of straw bales throughout their entire life cycle is lower than that of fired brick by $5.8 \%$ and cement block by $19.8 \%$. However, common construction materials, such as bricks and cement, are manufactured in Argentina, far away from the region of Andean Patagonia considered by the author. Thus, transport from 700 to $2000 \mathrm{~km}$ is required to deliver construction materials to the Andean Patagonia. Therefore, in this case, the use of straw from local cereal producers and frames built mostly with wood from local sources is a viable solution to increase the sustainability of buildings.

\section{Straw Bales Durability}

\subsection{Moisture Content Assessment}

Straw is a natural organic material; therefore, it is vulnerable to degeneration by certain values of humidity. One of the main concerns with straw bale buildings is the determination of moisture content within and surrounding the straw bales, since it is strictly related to straw decay: the higher the moisture level, the faster the straw will decay. In addition, a high level of humidity creates a suitable environment for mold growth, which is a risk to the user's health. In assessing straw degradation risks, it is important to consider the multiple environmental factors that affect the decay process, such as exposure duration [26].

Direct measurements are certainly the most reliable, but also the most difficult to perform, since they are too invasive when it comes to testing existing walls. On the contrary, indirect measurements, such as those linking moisture content in straw to relative humidity, are not invasive, but are less reliable, since they need to take into account different variables. "Direct measurement" refers to exactly measuring the moisture content in the straw bales, while "indirect measurement" refers to measuring the moisture content by measuring other parameters that are related to moisture content by means of equations. During the operative phase of a building, there are technical difficulties of taking 
direct measurements of rendered walls; therefore, it is necessary to develop an empirical relationship allowing one to measure moisture content indirectly.

A previous study [27] investigated the moisture and mold growth in straw bale walls through a combination of analyses, dynamic modeling, and field studies. The test walls were considered failures above $80 \%$ relative humidity. However, the extent of mold growth found within the walls after two years was not as significant as this limit would suggest. Raamets et al. [28] evaluated indoor air quality in two Estonian straw bale houses and provided a solution for monitoring indoor air quality and hygrothermal conditions. The results from air samples (in colony-forming units, CFU) in one house were higher than in the other one. The most fungal genes isolated from samples belonged to Aspergillus, Penicillium, Alternaria, and Cladosporium. Viel et al. [29] proposed a protocol for evaluating the resistance to mold contamination of bio-based composites. An accelerated aging test was carried out on five composites made with two different agro-resources (hemp and rape) and with different binders. The method consisted of exposing the specimens to $30^{\circ} \mathrm{C}, 90 \% \mathrm{RH}$ for three months.

Micro-organisms perform aerobic degradation in the presence of easily metabolized carbon and nitrogen. As the organisms run out of nutrients, they will no longer have an optimal substrate to support their growth. Two experiments were conducted by Thomson and Walker [26] to test if mold growth in straw bale walls decreases after initial colonization. In both experiments, the samples were exposed to high levels of humidity. In the first test, two samples were compared: one made of fresh straw and the other removed from the surface of a three-year-old wall panel. In the second test, six fresh straw specimens were exposed to two cycles of elevated humidity to evaluate the rate at which successive fungal colonization might become limited.

In the first test, the straw taken from the wall appeared discolored, though not significantly degraded. The two specimens were sealed at $87 \%$ relative humidity and held at a constant temperature of $21.5^{\circ} \mathrm{C}$. In order to ensure that the samples had equal moisture content at the start of the test, the specimens were both stored at $20{ }^{\circ} \mathrm{C}$ and $70 \%$ relative humidity for the seven days prior to testing. Carbon dioxide levels within the sealed containers were then monitored in order to detect microbial growth. As predicted, the three-year-old straw did not support any significant new microbial growth. On the other hand, a rapid increase in the $\mathrm{CO}_{2}$ concentration was observed for the fresh straw, indicating rapid microbial growth.

For the second experiment, the six wheat straw specimens were exposed to a range of different hygrothermal conditions. This second phase of testing investigated the impact of cyclically exposing fresh wheat straw to elevated levels of relative humidity. All the straw was conditioned at $20{ }^{\circ} \mathrm{C}$ and $70 \% \mathrm{RH}$ prior to testing. The six straw specimens were tested once again, but this time, the straw was initially exposed to a 28-day period of elevated relative humidity prior to a seven-day period of drying at $20{ }^{\circ} \mathrm{C}$ and $70 \% \mathrm{RH}$. The straw was then exposed for a second time to the same initial conditions for 14 days. The results confirmed what was expected: mold growth on the straw decreased drastically following initial growth due to exposure to high levels of humidity.

The Fraunhofer Institute of Building Physics [26] performed some experiments in order to test the mold resistance of construction materials. Wheat straw specimens were exposed to a range of climatic conditions, tweaking temperature and relative humidity (RH). The samples were visually monitored: over a time-span of 100 days, mold growth was only observed above $80 \% \mathrm{RH}$ at a temperature of $10^{\circ} \mathrm{C}$ and $70 \% \mathrm{RH}$ at a temperature of $25^{\circ} \mathrm{C}$. Once this threshold was crossed, mold growth would progress as the RH level increased.

Ashour et al. [30] carried out an extensive testing program, performing both in situ and laboratory tests in order to provide a complete picture of a two-story straw house in Germany. The in situ measurements evaluated temperature and relative humidity, using multiple NTC (negative temperature coefficient) sensors located on the surface and inside the straw bale walls, plastered on both the inside and the outside, in order to increase the overall durability of the construction. The moisture content of the straw was determined in the laboratory by putting the bales in an oven at $105^{\circ} \mathrm{C}$, until they reached a constant weight. The average moisture content registered during the tests was about $11 \%$, 
lower than the threshold value of $15 \%$, in order to prevent the deterioration of straw bale, as a result of the microbial activity according to Bainbridge [31]. Furthermore, the results showed the average $\mathrm{pH}$ value of the straw was 7.29 , slightly alkaline, which is typical for straw material.

In the same study, tests were performed on straw bales over a period of $450 \mathrm{~h}$ to determine their behavior in relation to relative humidity. The results showed that the relative humidity presented a steep increase and then continued increasing gradually until $450 \mathrm{~h}$. In addition, the difference between the surrounding relative humidity and the moisture content inside the bales decreased with time. This could be due to the low moisture content of straw. Therefore, it took a very long time to reach equilibrium with the outside conditions. Results of temperature and relative humidity measurements were within the hygrothermal comfort conditions. In addition, the outside temperatures measured in Bavaria, Germany, where the building was located, were smoothed out by straw walls. In conclusion, the authors stated that the time of some measurements was too short, particularly for the relative humidity in bales, which plays an important role in the long-term behavior of straw walls.

\subsection{Isotherm Relationships}

The hygrothermal characteristics of rendered straw bales need to be monitored in order to set a standard for the assessment of durability in straw bale construction and to find the relationship between moisture content within the material and relative humidity in the environment, known as the sorption isotherm, which is unique for each material [32]. There is a direct correlation between the moisture content of straw and the temperature and relative humidity of the surrounding environment [33].

Perry and Green [34] found that temperature reduction is determined by the lowering of the saturation vapor pressure, which allows water vapor molecules to condense into capillaries with wider diameters. However, this phenomenon only affects the sorption isotherms of straw for temperatures below $15^{\circ} \mathrm{C}$ and above $50^{\circ} \mathrm{C}$. Since the range in which decomposition occurs is $20-70{ }^{\circ} \mathrm{C}$, by crossing the values, it can be noticed that slight variations in the isotherm can occur below $15^{\circ} \mathrm{C}$.

Lawrence et al. [35] put different specimens through several testing cycles at different relative humidity values in order to determine isotherm relationships and to develop a model for predicting the moisture content of wheat straw based on relative humidity measurements. The tests were performed by placing straw samples in a scientific oven, set at different relative humidity levels and using saturated salt solutions. The data gathered showed that moisture content decreased with increasing temperature by $1-2 \%$ within the $5-26{ }^{\circ} \mathrm{C}$ range, but increased at the highest level of $98 \%$. These results do not support Perry and Green's approximation; however, the differences are not significant enough to invalidate it. Lawrence et al. [35] developed an equation to determine the sorption moisture content of grain straws, taking Hedlin's equation as a starting point:

$$
\varphi=\frac{1-K\left(1-\frac{C}{C_{s}}\right)}{1+\left[\frac{C}{\frac{C}{C_{s}}-1}\right]^{3 / i}}
$$

where $\varphi$ is the sorption moisture content, $C_{s}$ is the fiber saturation moisture content, $C$ is the equilibrium moisture content at the relative humidity, $C_{50 \%}$ is the equilibrium moisture content at $50 \%$ relative humidity, and $n, K$, and $i$ are constants with $n=C_{s} / C_{50 \%}$.

Lawrence et al. [35] neglected the variations occurring below $15^{\circ} \mathrm{C}$ and those occurring between the range of $50-70^{\circ} \mathrm{C}$, since these conditions are unlikely in the UK where the study was carried out. They took the temperature out of the equation, based on Perry and Green's consideration. They also rearranged the terms of the equation since the aim was to define relative humidity as a function of moisture content, and in Hedlin's equation, relative humidity is defined in terms of moisture content. 
The moisture content equation developed by Lawrence et al. [35] is:

$$
C=\frac{C_{s}}{1+n\left(\frac{K_{m}}{\varphi}-1\right)^{1 / 3}}
$$

where $K_{m}$ is $1-K$ as defined in Equation (1) and the constants $n, K_{m}$, and $i$ are empirically determined by Equation (1): $n=44 ; K_{m}=0.9773 ; K=0.0227 ; i=1.6$

The empirical relationship found by Lawrence et al. [35] has the limit of not taking the temperature into consideration. While this simplification was suitable for the climate conditions of the UK in which they operated, the same cannot be assumed for other climatic areas. Therefore, this relationship can only be used when straw bale moisture content is evaluated in similar climate conditions. However, in cold countries, like Canada, northern Europe, and the northern U.S., winter temperatures easily go below $15{ }^{\circ} \mathrm{C}$. This is a big limitation of the equation used by Lawrence et al. [35]. In fact, in cold climates, straw bale construction is especially attractive because of its insulation properties.

The empirical relationship developed between relative humidity and moisture content was then confirmed through tests conducted on wheat straw samples, in order to develop a pattern to assess moisture content based on relative humidity measurements.

These tests were performed by placing the samples in an oven, set at different relative humidity values and using saturated salt solutions.

Table 1 gathers the values of straw moisture content and relative humidity for each salt solution, at different temperatures, using Equation (2).

Table 1. Equilibrium moisture content (MC) (\% dry basis) of wheat straw at different temperatures and relative humidity $(\mathrm{RH})$ values [35].

\begin{tabular}{|c|c|c|c|c|c|c|c|c|c|c|c|}
\hline \multirow[b]{2}{*}{ Sample } & \multirow{2}{*}{$\begin{array}{l}\text { Saturated } \\
\text { Solution }\end{array}$} & \multicolumn{2}{|c|}{$5^{\circ} \mathrm{C}$} & \multicolumn{2}{|c|}{$10^{\circ} \mathrm{C}$} & \multicolumn{2}{|c|}{$15^{\circ} \mathrm{C}$} & \multicolumn{2}{|c|}{$20^{\circ} \mathrm{C}$} & \multicolumn{2}{|c|}{$26^{\circ} \mathrm{C}$} \\
\hline & & $\begin{array}{l}\text { Moisture } \\
\text { Content }\end{array}$ & $\begin{array}{l}\mathrm{RH} \\
(\%)\end{array}$ & $\begin{array}{c}\text { Straw } \\
\text { MC }\end{array}$ & $\begin{array}{l}\mathrm{RH} \\
(\%)\end{array}$ & $\begin{array}{c}\text { Straw } \\
\text { MC }\end{array}$ & $\begin{array}{l}\mathrm{RH} \\
(\%)\end{array}$ & $\begin{array}{c}\text { Straw } \\
\text { MC }\end{array}$ & $\begin{array}{l}\text { RH } \\
(\%)\end{array}$ & $\begin{array}{c}\text { Straw } \\
\text { MC }\end{array}$ & $\begin{array}{l}\mathrm{RH} \\
\text { (\%) }\end{array}$ \\
\hline 1 & $\mathrm{MgCl}_{2}$ & 7.97 & 33.6 & 7.14 & 33.5 & 6.57 & 33.3 & 6.44 & 33.1 & 5.80 & 32.8 \\
\hline 2 & $\mathrm{Mg}\left(\mathrm{NO}_{3}\right)_{2}$ & 14.82 & 58.9 & 14.38 & 57.4 & 13.83 & 55.9 & 11.78 & 54.4 & 13.17 & 52.9 \\
\hline 3 & $\mathrm{NaCl}$ & 14.84 & 76.7 & 14.58 & 75.6 & 14.36 & 75.6 & 14.13 & 75.4 & 13.42 & 75.3 \\
\hline 4 & $\left(\mathrm{NH}_{4}\right)_{2} \mathrm{SO}_{4}$ & 18.53 & 82.8 & 18.32 & 82.1 & 18.01 & 81.7 & 17.60 & 81.3 & 17.05 & 81.0 \\
\hline 5 & $\mathrm{~K}_{2} \mathrm{SO}_{4}$ & 48.44 & 98.5 & 47.15 & 98.2 & 46.51 & 97.9 & 49.34 & 97.6 & 51.49 & 97.3 \\
\hline
\end{tabular}

\subsection{Moisture Probes}

Straw bale moisture probes were originally used by farmers. The first to adapt them as an instrument for the quality control of straw bale constructions appears to be Gonzalez [25].

These probes were later used by Goodhew et al. [36] to conduct their tests on moisture content assessment of straw bale constructions. These probes consist of a timber disk screwed to two wires that come in contact with the wall, running through a perforated PVC pipe. The arrangement to be inserted into the straw bale wall is shown in Figure 2.

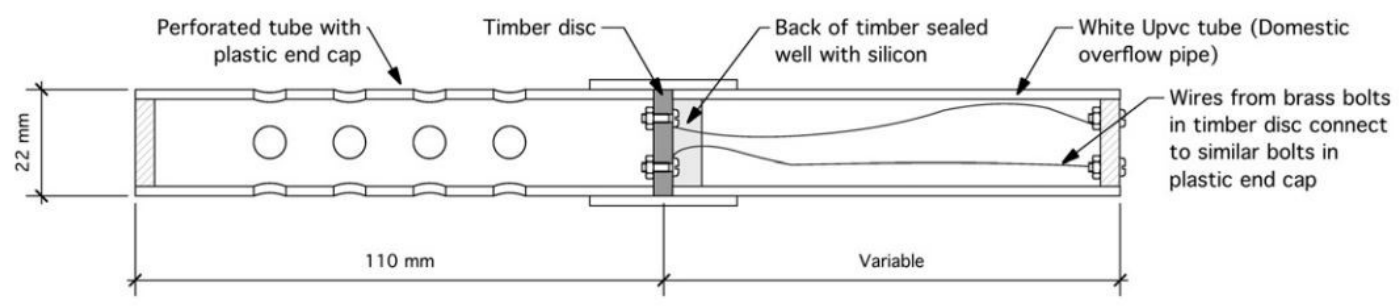

Figure 2. Section through original probe modified from the Canadian design [37].

The moisture content reached by the timber disc is supposed to equal that of the straw. 
This measurement is affected by temperature: at any given moisture content, the wood's electrical resistance decreases as temperature increases, especially at high MC values.

Goodhew et al. [36] implemented the original probe design by inserting a wooden disc into a perforated tube. The timber disc had a diameter of $22 \mathrm{~mm}$, was $5 \mathrm{~mm}$ thick, and was made of European oak. When the air inside the perforated tube stabilizes, it reaches equilibrium with the air surrounding the straw wall. Then, the timber disc adsorbs the relative humidity of the air inside the tube, registering the same moisture content as the straw. Finally, the timber disc moisture content is measured by an electrical resistance meter.

Carfrae et al. [37] gathered the results of moisture content measurements using both the Goodhew et al. [36] probe and a Protimeter Balemaster, which is a steel probe attached to a handheld meter. The comparison of several measurements obtained with the two devices showed that the Goodhew probe's measurements were consistently underestimating the moisture levels in the walls. This outcome underlined that the inaccuracy of the measurement recorded by the original probe is mainly due to the probe's design, or the type of wood used for the timber disc.

Carfrae et al. [37] developed three timber probe prototypes (Figure 3) with slight variations from the Goodhew et al. probe [36]. The aim was to compare the moisture content readings of all the prototype probes. The first prototype had a shorter perforated tube with larger holes than the Goodhew et al. probe [36], in order to expose the timber to a smaller volume of air. The tube was separated from the outside by a shroud with an end cap. The second prototype had a shorter shroud to keep the timber separated from the straw but had no end cap. Finally, in the third prototype, the timber disc was replaced by a timber bullet that was supposed to come in direct contact with the straw. The experiment was carried out by installing the prototype probes into an external wall of a straw bale house and drilling them through the render. Alongside the prototypes, a Balemaster, TES RH meter (electronic relative humidity meter), and Goodhew probe were installed. The probe readings stabilized after 20 days and the moisture content readings were taken after a further seven days.

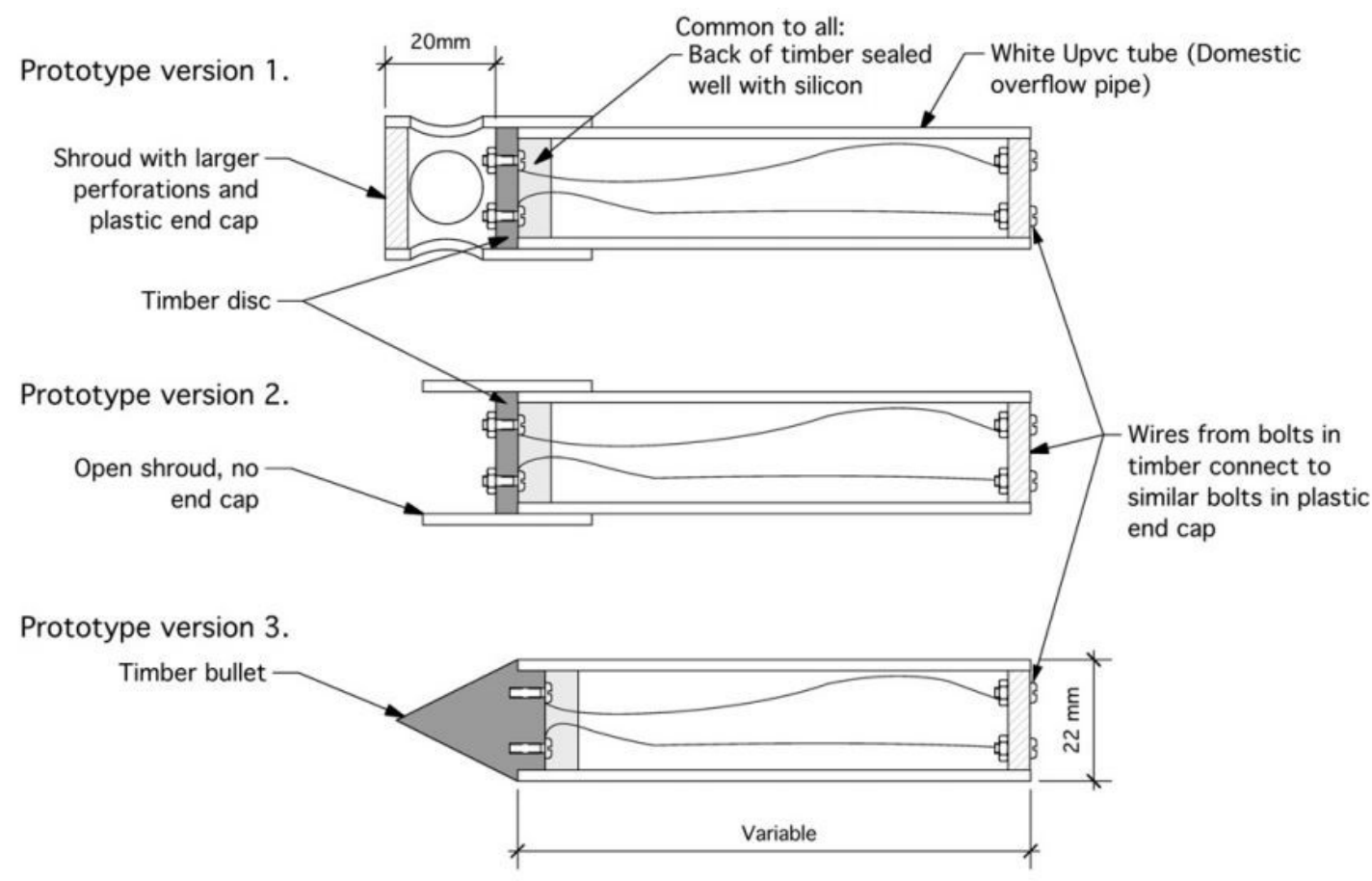

Figure 3. Prototype timber block probes [37].

All probes showed lower results than the Balemaster, as shown in Table 2, due to the process of the drying of straw and to the different isotherms between the wheat straw and timber species used 
for the discs. The isotherms showed that the better timber species was ramin. The same results were found by in-situ testing of other straw bale constructions.

Table 2. Moisture content (MC) values of prototype probes compared to the original probe [37].

\begin{tabular}{cc}
\hline Device & MC Readings \\
\hline Original probe & $10.9 \%$ \\
First prototype (vented shroud) & $13.4 \%$ \\
Second prototype (open shroud) & $13.0 \%$ \\
Third prototype (bullet tip) & $14.0 \%$ \\
Protimeter Balemaster & $15.0 \%$ \\
\hline
\end{tabular}

After selecting the most suitable timber species, further tests were performed in the same straw house with 48 pairs of prototype probes. The new prototype was designed with a bullet shaped tip and inserted into a PVC tube that was $350 \mathrm{~mm}$ long. The probes were calibrated at $80 \%$ relative humidity. One of the probes was moistened, in order to see if the isotherms show a hysteresis effect. The measurements were also performed with a Balemaster and relative humidity meter as references. At relative humidity ranging between $88 \%$ and $90.5 \%$, the saturated probe registered moisture content between $20 \%$ and $20.5 \%$, while the dry probe registered $18.8 \%$ to $19.8 \%$. These results were consistent with those anticipated when studying the isotherms; however, the readings did not follow relative humidity variations as closely as expected.

The probe developed using the results from in situ testing and laboratory isotherms presented significant advantages: it is easy to produce and use, inexpensive, and can be left installed for continuous monitoring of the moisture content of straw bale walls.

\section{Thermal Performance}

Different studies analyzed the thermal properties of straw bales [38]. Ren et al. [39] developed and applied new types of straw block in the north wall of solar greenhouses. The thermal properties of the new types of straw block north wall were higher than those of a porous clay block north wall. At the depths of $0,80,160$, and $240 \mathrm{~mm}$, the temperatures of straw block were $0.5,0.6,0.8$, and $1.2{ }^{\circ} \mathrm{C}$ higher than those of clay block, respectively. In addition, compared to the solar greenhouse with a porous clay block north wall, the air temperature of new types of straw block north wall was $0.5^{\circ} \mathrm{C}$ higher during nighttime, and the average relative humidity was $5.3 \%$ lower during nighttime. The results showed that the new types of straw block north wall had better thermal and wet environment characteristics, and it was durable and suitable for the growth of crops. Rojas et al. [40] developed block type insulation based on wheat straw and corn husk residual fibers. The research showed that thermal conductivity values were between 0.046 and $0.047 \mathrm{~W} / \mathrm{mK}$. Nasser et al. [41] made a composite of rice straw particles bounded by a polymer to produce roof insulations. Satisfying results were achieved to nominate the $80 \%$ polyurethane foam and $20 \%$ rice straw composite as the best sample among all of the prepared samples. The foam and straw sample have the best insulation with value of $0.1627 \mathrm{~W} / \mathrm{m}^{\circ} \mathrm{C}$.

Tests on conductivity values found in the literature were conducted using small samples, whereas straw bales have a larger thickness than most of the insulating materials. Consequently, the measurement apparatus for thermal conductivity is usually not designed for such thickness. Costes et al. [42] presented a measuring campaign performed with a specific Guarded Hot Plate according to Dubois and Lebeau [43], designed to measure samples up to $50 \mathrm{~cm}$ thick, in order to guarantee reliable measurements. In particular, the influence of density and thickness on the thermal conductivity of the samples were investigated. The results demonstrated that, for a given wall width, the thermal conductivity $\lambda$, as well as the thermal transmission coefficient $U$, may be improved by about $25 \%$, according to the density of the bale. For an average density about $100 \mathrm{~kg} / \mathrm{m}^{3}$, the calculated thermal transmission coefficient varies between 0.2 to $0.15 \mathrm{~W} / \mathrm{m}^{2} \mathrm{~K}$, according to the bale 
width. Similarly, Conti et al. [44] developed cheap and simple equipment and procedures suitable for the assessment of the thermal performance of full-size rectangular straw bales of various nature and origin. To this end, the guidelines of ASTM and ISO standards were followed to the extent they can be applied. The results obtained were found to be comparable with Costes et al. [42] results. Finally, Seitz and MacDougall [45] described the design and construction of a small-scale, affordable hot box apparatus for testing of straw bale and other nonconventional building panels. The apparatus met the minimum metering area and minimum number of temperature sensors per unit of wall area stipulated by ASTM C1363.

It is also necessary to investigate the characteristics of the specific straw used (i.e., wheat, rice, barley, etc.), since they vary for different specimens [46]. Recently, some researchers have analyzed this topic with the aim of finding a pattern for the thermal behavior of straw bale buildings and to achieve certified straw bale constructions. D'Alessandro et al. [47] conducted laboratory and in-field tests to assess straw bale performance. The laboratory tests on thermal conductivity were performed following the procedure defined by the Standard EN 12667 [48]. The straw was provided by local cultivations and the measurements were carried out through a one-sample guarded hot plate. The straw was located inside a wooden frame and the measurements considered the core of the sample, which is less affected by the surrounding laboratory conditions. The bale was tested in a flat position, although it is worth mentioning that Chaussinand's results [49] showed that straw bales perform better when laid on their edge. The heat flux generated inside the sample was measured by the Joule effect. The density of the straw bales was $80 \mathrm{~kg} / \mathrm{m}^{3}$. The results of the thermal conductivity were gathered over a period of eight hours, starting from steady-state conditions, and were consistent with the values found in the literature, such as those found by Chaussinand [49]—ranging between 0.050 and $0.060 \mathrm{~W} / \mathrm{mK}$, as anticipated. The results were also compared to similar tests conducted by the Austrian Center for Appropriate Technology [50] using a guarded hot plate, which are quite different: the average value found was $0.038 \mathrm{~W} / \mathrm{mK}$, which seems unrealistic considering that it is comparable to the thermal conductivity of high insulation materials.

D'Alessandro et al. [47] also performed in-situ measurements on an existing construction in central Italy: a post and beam infill building using $45 \times 35 \times 1.10 \mathrm{~cm}$ straw bales with an $80 \mathrm{~kg} / \mathrm{m}^{3}$ density. In the laboratory, the thermal transmittance was calculated in steady state conditions; in situ measurements are considered more reliable and, for this, it was calculated from temperature measurements performed in situ using thermal flux sensors, according to Standard EN 1934 [51]. The thermal flux meters were positioned in two areas: in the straw bale insulation and in the wooden frame, where thermal bridges might occur. Better values of thermal transmittance were found in the straw bale insulation area than close to the wooden frame; $0.119 \mathrm{~W} / \mathrm{m}^{2} \mathrm{~K}$ and $0.253 \mathrm{~W} / \mathrm{m}^{2} \mathrm{~K}$, respectively.

Overall, tests showed that the thermal conductivity of straw is not comparable to traditional insulating material performance. Buratti et al. [10] investigated a multisheet wall by analyzing the thermal properties of straw by means of a new experimental apparatus named the Small Hot-Box. The straw had a thermal conductivity of about $0.065 \mathrm{~W} / \mathrm{mK}$. Jelle [52] investigated and compared the thermal properties of different building insulation materials and solutions. The author stated that typical thermal conductivity values for mineral wool, extruded polystyrene (XPS), and expanded polystyrene (EPS) are between 0.030 and $0.040 \mathrm{~W} /(\mathrm{mK})$; these are currently the most common traditional thermal building insulation materials with relatively low thermal conductivity.

Since thermal resistance is affected by density, several authors analyzed the thermal conductivity with varying straw density (Figure 4) [42]. 


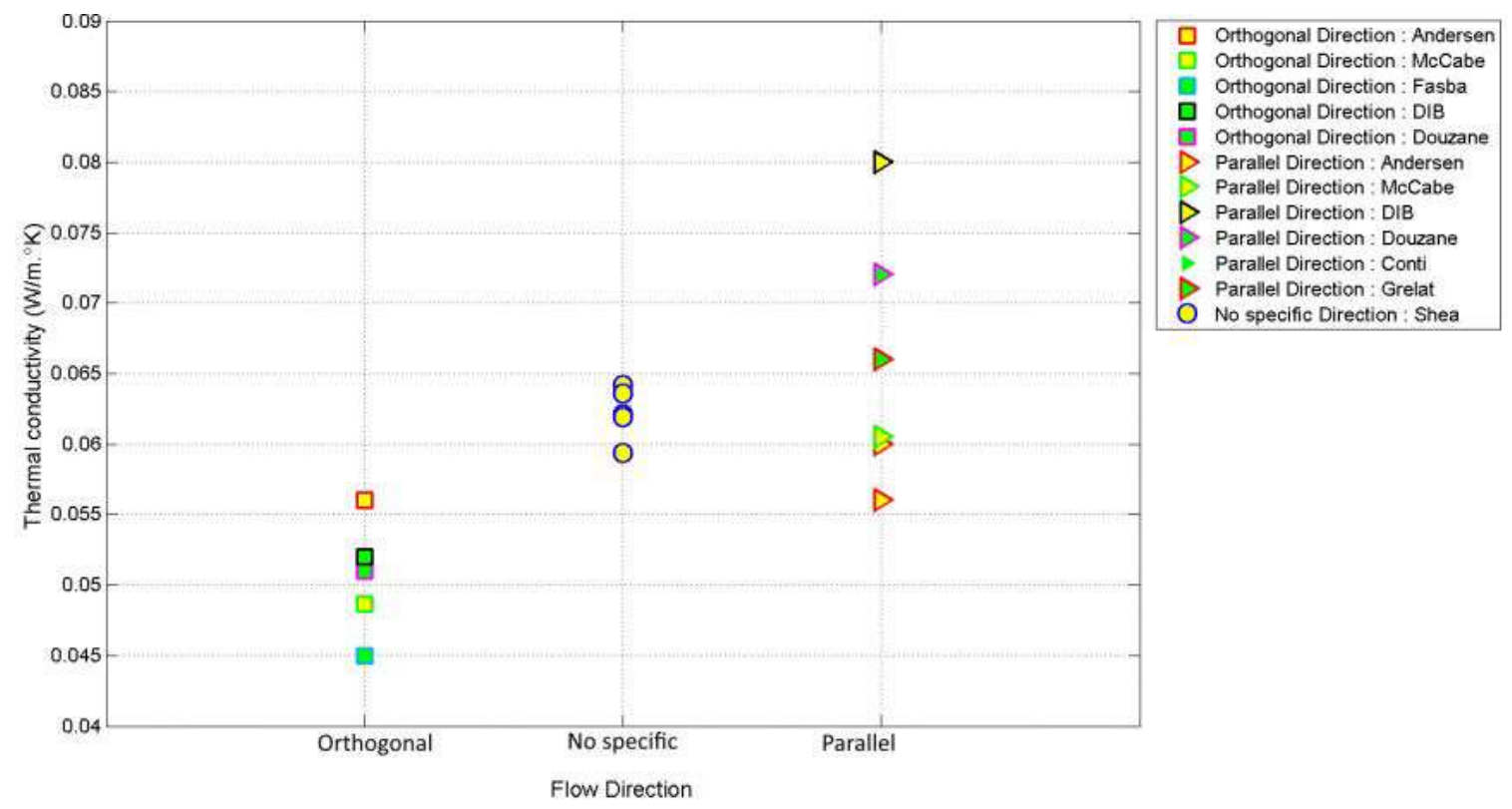

Figure 4. Effect of bale density on thermal conductivity [42].

Seitz et al. [53] obtained the thermal conductivity values for four panels with densities ranging from $89.5 \mathrm{~kg} / \mathrm{m}^{3}-131 \mathrm{~kg} / \mathrm{m}^{3}$ and for three panels with densities ranging from $291 \mathrm{~kg} / \mathrm{m}^{3}-372 \mathrm{~kg} / \mathrm{m}^{3}$. The authors concluded that there was no difference in the thermal conductivity value for panels using normal density bales and manufactured high density bales up to a density of $333 \mathrm{~kg} / \mathrm{m}^{3}$. Shea et al. [54] studied the thermal conductivity with a flow meter on various samples of straw with a thickness of $25 \mathrm{~cm}$, compressed to reach a large range of densities. The measured thermal conductivities ranged from $0.059 \mathrm{~W} / \mathrm{mK}$ for a density of $63 \mathrm{~kg} / \mathrm{m}^{3}$ to $0.064 \mathrm{~W} / \mathrm{mK}$ for a density of $123 \mathrm{~kg} / \mathrm{m}^{3}$. The authors proposed a reference value of $0.065 \mathrm{~W} / \mathrm{mK}$. In general, considering a given thermal flow direction, these results showed a rise in thermal conductivity as the density increased.

Galleros-Ortega et al. [46] studied the thermal behavior by in situ monitoring of a straw bale building located in Tecate, Mexico. The investigated construction was a $36.3 \mathrm{~m}^{2}$ building with load-bearing walls made with laid flat three-wire wheat straw, with bales of $40 \times 60 \times 120 \mathrm{~cm}$ and a density of $115.5 \mathrm{~kg} / \mathrm{m}^{3}$. Samples were taken from the building to measure moisture content, which was reported to be $10.5 \%$. The walls were rendered on the outside and inside with a $2.5 \mathrm{~cm}$ layer of earth plaster. The monitoring was conducted on the south facing wall, because of its full exposure to sunlight.

Two thermocouples were placed on both sides of the investigated wall. A heat flow sensor was placed on the right below the thermocouple and a black globe sensor was located in the center of the room. Finally, the last sensor was positioned outside, in order to monitor air temperature. The results of the monitoring showed that, even for an outside temperature ranging from 12 to $50{ }^{\circ} \mathrm{C}$, the interior temperature barely presented a fluctuation of $2{ }^{\circ} \mathrm{C}$. Figure 5 represents the hourly average values for the entire monitoring test and shows how the internal temperature remains stable despite outside temperature fluctuations [46]. 


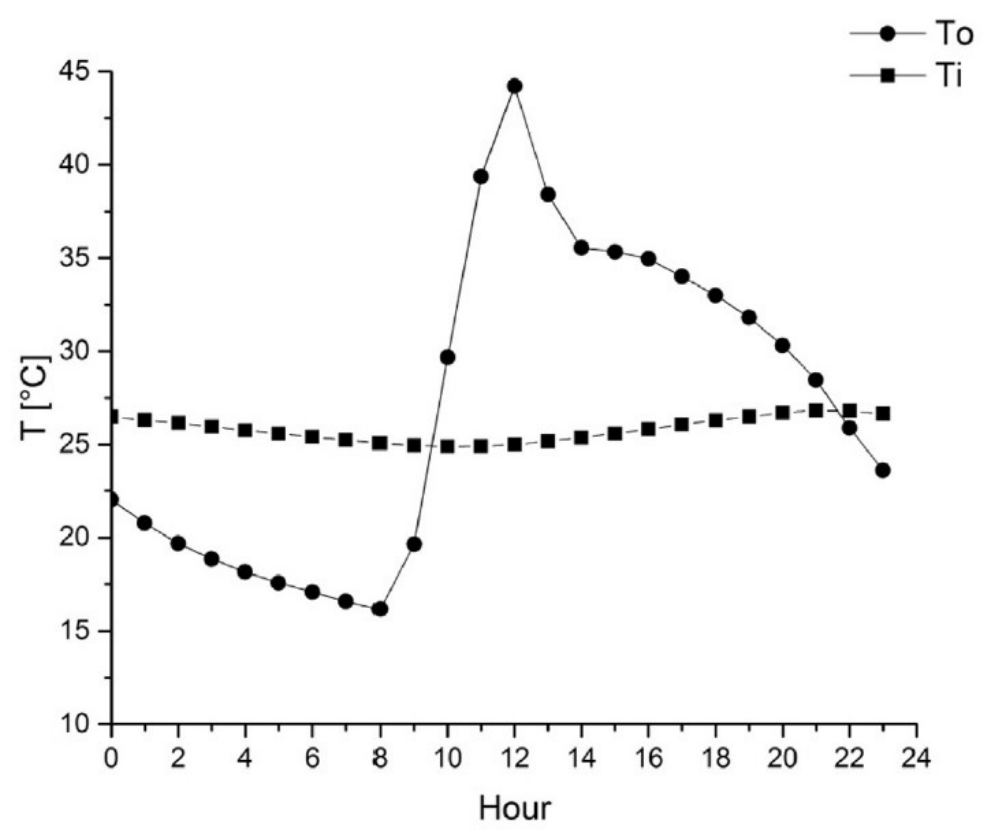

Figure 5. Average hourly exterior wall surface temperature for the entire period [46].

From the temperature data collected in situ, time lag and temperature damping were determined using Equations (1) and (2), respectively:

$$
\begin{gathered}
\varphi=h_{\text {max }_{i}}-h_{\text {max }_{0}} \\
\Psi=\frac{T_{0}}{T_{i}}
\end{gathered}
$$

where $\varphi$ is the time lag and $\psi$ is the temperature damping.

The duration of the tests carried out by Galleros-Ortega [46] can be considered sufficiently extended to gather significant data, since over 66 monitoring days, there was a $95 \%$ probability the values occurred. Considering the average results, a time lag of $9.12 \mathrm{~h}$ and a temperature damping of $93.6 \%$ were determined. Thermal conductivity and thermal resistance of $0.0939 \mathrm{~W} / \mathrm{m}^{\circ} \mathrm{C}$ and $6.92 \mathrm{~m}^{2 \circ} \mathrm{C} / \mathrm{W}$, respectively, were calculated. The calculated thermal properties values are reported in Table 3 . The main dynamic effects are time lag and temperature damping. The time lag is the relation that exists between the time that the highest interior temperature occurs and the time of the highest temperature measured on the outside of the slab. The temperature damping is the relation between the temperature oscillation of the inside face to that of the outer face.

Table 3. Results of time lag and temperature damping [46].

\begin{tabular}{ccccc}
\hline & $\boldsymbol{\varphi}(\mathbf{h})$ & $\boldsymbol{\Psi}(\mathbf{\%})$ & $\begin{array}{c}\text { Thermal Resistance } \\
\mathbf{m}^{\mathbf{2}}{ }^{\circ} \mathbf{C} / \mathbf{W}\end{array}$ & $\begin{array}{c}\text { Thermal Conductivity } \\
\mathbf{W} / \mathbf{m}^{\circ} \mathbf{K}\end{array}$ \\
\hline Mean & 9.12 & 93.57 & 6.92 & 0.0939 \\
Lower limit & 8.96 & 94.88 & 7.01 & 0.0856 \\
Upper limit & 9.29 & 92.26 & 6.83 & 0.0878 \\
Uncertainty (\%) & 1.8 & 1.4 & 1.3 & 1.3 \\
\hline
\end{tabular}

These results were compared to laboratory tests performed by Belhadj et al. [55], that obtained time lag ranging from 4 to $9 \mathrm{~h}$ and temperature damping varying from 15 to $85 \%$. Therefore, the results were consistent with the Galleros-Ortega [46] results as far as time lag is concerned, while Galleros-Ortega's tests delivered better results in terms of temperature damping. 


\section{Acoustic Performance}

Deverell et al. [56] performed tests to assess the acoustic insulation performance of wheat straw bale walls on the Genesis Centre at Somerset College of Arts and Technology, a pavilion constructed with a load-bearing system. The aim was to investigate whether the insulation performance of straw bales is suitable for educational buildings, which have strict acoustic requirements.

The measurements were taken according to ISO 140-4:1998 [57]. Three rooms, separated by two partitions made of bales, were monitored (Figure 6). Partition A has a plastered surface on one side and a flax board surface on the other; partition $B$ has a flex board surface on both sides. First, measurements were performed through partition A with room 1 as the source and room 2 as the receiving end. The second set of tests was carried out through partition $\mathrm{B}$, using room 2 as the source and room 3 as the receiver. The results for partition $A$, separating rooms 1 and 2, registered an average sound insulation of $49.5 \mathrm{~dB}$, while for partition $\mathrm{B}$, the tests delivered an average value of $49 \mathrm{~dB}$. These values represent the weighted standardized level difference, expressed in decibels, between the average sound pressure level in the source room and the receiving room. The air circulating in the hollow space between the straw bale wall and its covering contributed to a damping of the sound waves through the partitions. Even though the render affected the results, enhancing the sound insulation properties of the partitions, it should be noted that a surface coating is always used for aesthetic and functional reasons, especially when dealing with modern buildings

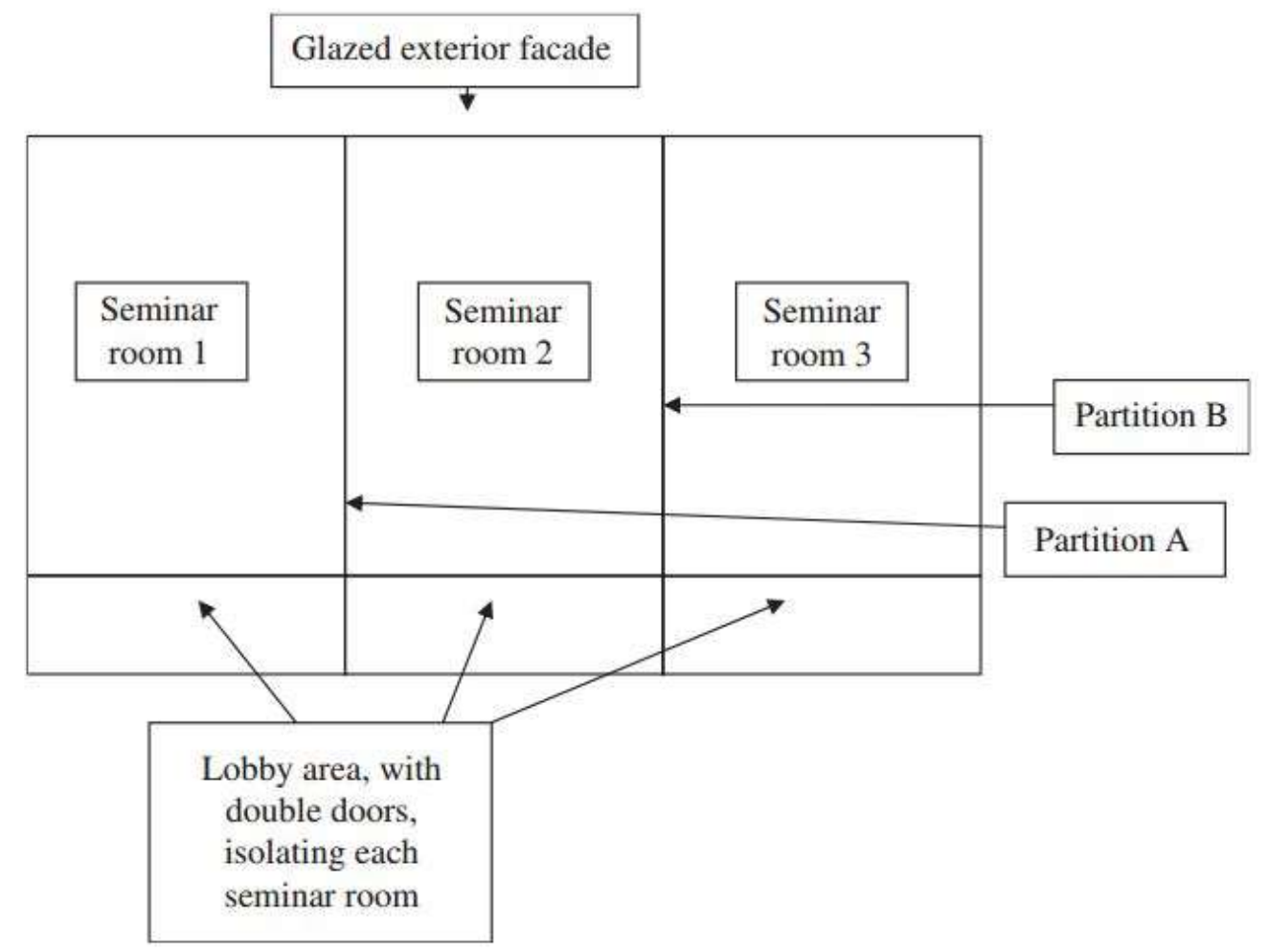

Figure 6. Layout of the tested Genesis Centre straw bale seminar rooms [56].

These results are consistent with the required performance in the UK, the minimum values required by the building regulations Approved Document part E (ADE) [58] and the regulation pertaining to sound requirement insulation standards for schools and educational buildings; in particular, Building Bulletin 93 of the DfES (Department for Education and Skills) reports the guidelines for acoustic comfort in classrooms.

It is worth noting that the weighted values are calculated as an average of only two readings. These values, calculated according to UK standards, can be adjusted to suit the parameters set by other countries; for instance, the weighted standardized level difference can shift to the Apparent Sound 
Reduction Index that is normally used outside the UK. As an example, in Italy, the acoustic level for educational buildings is $50 \mathrm{~dB}$. Table 4 shows building acoustic requirements according to D.P.C.M. 5/12/97 [59].

Table 4. Comparison sound insulation measurements [56].

\begin{tabular}{ccc}
\hline Deverell Results & $\begin{array}{c}\text { Requirements of Approved } \\
\text { Document Part E (ADE) }\end{array}$ & $\begin{array}{c}\text { DfES's Building Bulletin 93 for } \\
\text { High Activity Noise }\end{array}$ \\
\hline $49 \mathrm{~dB}$ average & $45 \mathrm{~dB}$ separating & 45 (high noise tolerance) \\
$53 \mathrm{~dB}(\mathrm{R})$ average & $40 \mathrm{~dB}(\mathrm{R})$ partitions & 50 (medium to low noise tolerance) \\
$53 \mathrm{~dB}\left(R_{w}^{\prime}\right)$ average & & 55 (very low noise tolerance) \\
$51 \mathrm{~dB}\left(D_{w}\right)$ & & \\
\hline
\end{tabular}

The categories reported in Table 5 are:

- A: residential buildings and similar

- B: office buildings and similar;

- C: hotels, hostels and similar;

- D: hospitals, clinics, hospices and similar;

- E: educational buildings and similar;

- F: buildings for leisure activities or religious buildings and similar;

- G: buildings for marketing activities and similar.

Table 5. Buildings' passive acoustic requirements [59].

\begin{tabular}{ccc}
\hline \multirow{2}{*}{ Categories } & \multicolumn{2}{c}{ Parameters } \\
\cline { 2 - 3 } & $\boldsymbol{R}_{\boldsymbol{w}}^{\prime}$ & $\boldsymbol{D}_{2 m, n T, \boldsymbol{w}}$ \\
\hline 1. D & 55 & 45 \\
2. A, C & 50 & 40 \\
3. E & 50 & 48 \\
4. B, F, G & 50 & 42 \\
\hline
\end{tabular}

Parameters:

- $\quad R_{w}^{\prime}$ : weighted apparent soundproof ability of room separating elements;

- $D_{2 m, n T, w}$ : standardized façade acoustic insulation.

The tests conducted by D'Alessandro et al. [47] involved acoustic measurements on the façade's sound insulation, according to the Standard ISO 16283-3 [60], which defines the level difference as:

$$
D_{2 m}=L_{1,2 m}-L_{2}
$$

where $L_{1,2 m}$ is the sound pressure level measured $2 \mathrm{~m}$ in front of the façade and $L_{2}$ is the average sound pressure level measured inside the receiving room.

The level difference was then calculated by an equation introducing a correction term to take into consideration the reverberation time:

$$
D_{2 m, n T}=D_{2 m}+10 \log \left(\frac{T}{T_{0}}\right)
$$

where $T$ is the reverberation time measured in the receiving room and $T_{0}=T_{0} 0.5 \mathrm{~s}$ is the reference reverberation time for dwellings.

The measurements were performed according to the Standard ISO 354 [61], within a 100-500 Hz frequency range, without background noise. The results were reported as a function of the apparent 
sound reduction index $\mathrm{R}^{\prime}$ and then correlated to the level difference through an equation defined by the European standard EN 12354-3 [62].

The measurements performed through in situ façade tests showed that the investigated wall performed poorly, especially at a low frequency, due to its lightweight nature. The numerical values deduced by the test delivered a standardized level difference of $48 \mathrm{~dB}$ and a weighted apparent sound reduction index of $42 \mathrm{~dB}$, lower than the legal requirements. These values are far from those achieved by conventional materials.

\section{Critical Analysis}

The results currently available in the literature do not cover the entire spectrum of acoustic characteristics of straw bale buildings and they are insufficient to inform construction practice.

Even though it is necessary to take into consideration that the comparison of the results shown in Table 6 occurs between partition walls and façade walls, the outcomes highlight that the wall render affects the building performance, since rendered walls performed significantly better than the straw. This phenomenon is due to the higher density of the wall than the straw. Furthermore, as the sound waves travel through the wall, they encounter the air present inside the gap between the render coating and the wall itself, muffling the sound in the receiving room.

Table 6. Comparison between the results found by Deverell et al. [56] and D'Alessandro et al. [47].

\begin{tabular}{ccc}
\hline & Deverell et al. [56] & D'Alessandro et al. [47] \\
\hline Construction technique & $\begin{array}{c}\text { Load-bearing straw bale partitions } \\
\text { (partition A and partition B) }\end{array}$ & Post and beam with straw infill \\
\hline Render & $\begin{array}{c}\text { Partition A: plastered surface on one side } \\
\text { and flax board surface on the other; } \\
\text { Partition B: plastered surface on both sides }\end{array}$ & Earth plaster render \\
\hline Wall thickness & $45 \mathrm{~cm}$ & $45 \mathrm{~cm}$ \\
\hline Weight & $30 \mathrm{~kg}$ & $\mathrm{~N} / \mathrm{A}$ \\
\hline Density & $\mathrm{N} / \mathrm{A}$ & $80 \mathrm{~kg} / \mathrm{m}^{3}$ \\
\hline Sound insulation results & $49 \mathrm{~dB}$ & $42 \mathrm{~dB}$ \\
\hline
\end{tabular}

As far as thermal properties are concerned, D'Alessandro et al. [47] and Galleros-Ortega et al. [46] showed quite comparable results. Galleros-Ortega et al. [46] focused on time lag and temperature damping assessment, while D'Alessandro et al. [47] focused on thermal transmittance and thermal conductivity. The results found by Galleros-Ortega et al. [46], in terms of time lag and temperature damping, show significant figures consistent with previous research.

It is generally recommended that thermal bridges and cold elements within the straw are avoided, as these may allow water vapor present in the straw to condense. For this reason, metal framings or fixings are often avoided or at least wrapped in sackcloth to separate them from contact with the straw. Preliminary thermographic camera surveys and heat flux measurements carried out by D'Alessandro et al. [47] allowed evaluation of the thermal transmittance of the wall and its thermal bridges. Based on the outcomes of a thermographic survey, the thermal flux meters and the temperature probes were placed far from the wooden structure to evaluate the relative heat loss, in correspondence with the thermal bridge created by the wooden structure. The authors found that even though straw bale walls perform much better around the straw insulation than the wooden frame in terms of thermal transmittance, the influence of thermal bridges does not significantly affect the overall energy efficiency of the envelope. To the authors' knowledge, only one other study [63] has considered the role of the thermal bridge on the thermal behavior of straw bales, using an FEM program.

Combining the use of straw bale walls with a render or any type of high-density layer could improve both the thermal and acoustic properties of straw bale constructions. 
Study results gathered from tests performed by multiple authors show that the use of straw bale buildings as a common practice is a solid possibility.

In order to back up the development of straw bale constructions, it is crucial to gather information regarding a few basic issues, such as the degradation patterns of straw bales. The major issue is that amongst the methods used to measure and monitor moisture content within straw bales, including electrical resistivity, there is not one that provides a reliable empirical relationship.

Another issue is the strict guidelines required for construction practices that exist to avoid rapid decay of the material, even though the consequences of exposure to degradation factors are unclear.

Amongst the possible solutions to make straw bale buildings a mainstream construction technique, the first step is to set guidelines for the characteristics that must be achieved during the baling process, such as standard dimensions, density, fiber orientation, and so forth, since standard characteristics are one of the advantages of traditional materials over innovative ones. Straw bales could then be standardized globally and formally certified.

It is important to ensure that bales are tightly bound and relatively consistent in dimension and density. Typical dimensions for straw bales are $990 \times 500 \times 375 \mathrm{~mm}$. Bales should be laid flat to form walls 450-500 $\mathrm{mm}$ thick once finishes have been applied. However, bales can also be laid 'on edge' to form walls around $100 \mathrm{~mm}$ thinner, although this would provide a corresponding reduction in insulation value. Straw bale density for construction should normally be no less than $110 \mathrm{~kg} / \mathrm{m}^{3}$ to provide robustness in transport, stability, and fire resistance.

In conclusion, the recommended properties of straw bale are:

- minimum bale dry density: $110-150 \mathrm{~kg} / \mathrm{m}^{3}$

- thermal conductivity: $0.055-0.065 \mathrm{~W} / \mathrm{mK}$

- maximum in-service moisture content: not normally exceeding $20 \%$

\section{Conclusions}

The aim of this review is to highlight the solid results achieved so far by studies on the topic of straw bale buildings, as well as to identify the weakest aspects that need to be further investigated.

Some of the studies analyzed represent an important step forward in the introduction to straw bale building practices as a recognized construction technique, especially in situ testing, which gives a quantitative assessment of the physical and mechanical properties.

On the other hand, the lack of consistent data related to some aspects is due to the wide variety of characteristics that this material itself presents.

Setting rigorous standards for straw bales would help predict the behavior of the building envelope and its response to specific environmental conditions, since this would narrow down the range of numerical values corresponding to the material properties. For example, setting density requirements for straw bales would provide a specific range of sound and thermal insulation values.

A quantitative assessment of some of the most significant properties, such as the thermal resistance and acoustic insulation, is the starting point to closing the gap between those who support innovative construction systems because of their sustainability characteristics and professionals who are hesitant to give up on traditional materials which guarantee better control over their performance in terms of living comfort.

In situ testing should be conducted in different climate areas using different straw specimens and different building configurations, taking existing data as a baseline, in order to easily compare results and deliver a full assessment in the future.

Author Contributions: Conceptualization, S.C.; methodology, S.C.; formal analysis, R.R.; investigation, D.C.; resources, D.C.; data curation, R.R.; writing-original draft preparation, S.C. and R.R.; writing-review and editing, S.C.; visualization, S.C.; supervision, S.C. and D.C.; project administration, S.C. and D.C.; funding acquisition, S.C. and D.C.

Funding: This research was funded by "the Notice 5/2016 for financing the Ph.D. regional grant in Sicily" as part of the Operational Program of European Social Funding 2014-2020 (PO FSE 2014-2020). 
Conflicts of Interest: The authors declare no conflict of interest.

\section{References}

1. Gellert, R. Inorganic mineral materials for insulation in buildings. Mater. Energy Effic. Therm. Comf. Build. 2010, 193-228. [CrossRef]

2. Wang, H.; Chiang, P.C.; Cai, Y.; Li, C.; Wang, X.; Chen, T.L.; Wei, S.; Huang, Q. Application of wall and insulation materials on Green building: A review. Sustainability 2018, 10, 3331. [CrossRef]

3. Dutil, Y.; Rousse, D.; Quesada, G. Sustainable buildings: An ever evolving target. Sustainability 2011, 3 , 443-464. [CrossRef]

4. Global Information and Early Warning System (GIEWS). Crop Prospects and Food Situation; GIEWS: Rome, Italy, 2019.

5. Drozd, W.; Leśniak, A. Ecological wall systems as an element of sustainable development-cost issues. Sustainability 2018, 10, 2234. [CrossRef]

6. Palmieri, N.; Forleo, M.B.; Giannoccaro, G.; Suardi, A. Environmental impact of cereal straw management: An on-farm assessment. J. Clean. Prod. 2017, 142, 2950-2964. [CrossRef]

7. Wang, X.; Li, K.; Song, J.; Duan, H.; Wang, S. Integrated assessment of straw utilization for energy production from views of regional energy, environmental and socioeconomic benefits. J. Clean. Prod. 2018, 190, 787-798. [CrossRef]

8. Cascone, S.; Catania, F.; Gagliano, A.; Sciuto, G. Energy performance and environmental and economic assessment of the platform frame system with compressed straw. Energy Build. 2018, 166, 83-92. [CrossRef]

9. La Gennusa, M.; Llorach-Massana, P.; Montero, J.I.; Peña, F.J.; Rieradevall, J.; Ferrante, P.; Scaccianoce, G.; Sorrentino, G. Composite building materials: Thermal and mechanical performances of samples realized with hay and natural resins. Sustainability 2017, 9, 373. [CrossRef]

10. Buratti, C.; Belloni, E.; Merli, F.; Zanella, V.; Robazza, P.; Cornaro, C. An innovative multilayer wall composed of natural materials: Experimental characterization of the thermal properties and comparison with other solutions. Energy Procedia 2018, 148, 892-899. [CrossRef]

11. Barbaresi, A.; Dallacasa, F.; Torreggiani, D.; Tassinari, P. Retrofit interventions in non-conditioned rooms: Calibration of an assessment method on a farm winery. J. Build. Perform. Simul. 2017, 10, 91-104. [CrossRef]

12. Whitman, C.J. Straw bales, a possible solution for hygro-thermally comfortable dwellings in Chile's central valley: Physical test chambers and in situ measurements. J. Green Build. 2014, 9, 161-181. [CrossRef]

13. Sabapathy, K.A.; Gedupudi, S. Straw bale based constructions: Measurement of effective thermal transport properties. Constr. Build. Mater. 2019, 198, 182-194. [CrossRef]

14. King, K. Design of Straw Bale Buildings: The State of the Art; Green Building Press: San Rafael, CA, USA, 2006.

15. Yin, X.; Lawrence, M.; Maskell, D.; Ansell, M. Comparative micro-structure and sorption isotherms of rice straw and wheat straw. Energy Build. 2018, 173, 11-18. [CrossRef]

16. Yin, X.; Lawrence, M.; Maskell, D. Straw bale construction in northern China-Analysis of existing practices and recommendations for future development. J. Build. Eng. 2018, 18, 408-417. [CrossRef]

17. Vardy, S.; MacDougall, C. Compressive Testing and Analysis of Plastered Straw Bales. J. Green Build. 2010, 1, 63-79. [CrossRef]

18. Beaudry, K.; MacDougall, C. Structural performance of non-plastered modular straw bale wall panels under transverse and gravity loads. Constr. Build. Mater. 2019, 216, 424-439. [CrossRef]

19. Conti, L.; Barbari, M.; Monti, M. Design of Sustainable Agricultural Buildings. A Case Study of a Wine Cellar in Tuscany, Italy. Buildings 2016, 6, 17. [CrossRef]

20. International Code Council. IRC_International Residential Code for One and Two Family Dwellings; International Code Council: Washington, DC, USA, 2018.

21. Apte, V.B.; Paroz, B.; Bhargava, A. A fire safety testing and modeling of rendered straw bales for construction in bushfire prone areas. In Proceedings of the 4 th International Seminar on Fire and explosion Hazards, Londonderry, UK, 8-12 September 2003; pp. 537-546.

22. Marković, V.; Milić, M. Thermal insulation properties and fire resistanza of walls with straw bale filling. In Contemporary Achievements in Civil Engineering; University of Novi Sad: Subotica, Serbia, 2018; pp. $297-304$.

23. Teslík, J.; Vodičková, M.; Kutilová, K. The Assessment of Reaction to Fire of Crushed Straw. Appl. Mech. Mater. 2016, 824, 148-155. [CrossRef] 
24. Nozdrovicky, L.; Macak, M.; Maga, J. Evaluation of the technical and economical effects of the using of machinery system for processing of straw for energy purposes. Agric. Eng. Int. CIGR J. 2015, 2015, $200-207$.

25. González, A.D. Energy and carbon embodied in straw and clay wall blocks produced locally in the Andean Patagonia. Energy Build. 2014, 70, 15-22. [CrossRef]

26. Thomson, A.; Walker, P. Durability characteristics of straw bales in building envelopes. Constr. Build. Mater. 2014, 68, 135-141. [CrossRef]

27. Bronsema, N.R. Moisture Movement and Mould Management in Straw Bale Walls for a Cold Climate. Master's Thesis, University of Waterloo, Waterloo, ON, Canada, 2010.

28. Raamets, J.; Ruus, A.; Ivask, M. Assessment of Indoor Air Quality and Hygrothermal Conditions of Boarders During Autumn, Winter and Spring in Two of Estonian Straw-Bale Houses. In Cold Climate HVAC Conference; Johansson, D., Bagge, H., Wahlström, Å., Eds.; Springer: Cham, Germany, 2019; pp. 815-823.

29. Viel, M.; Collet, F.; Lecieux, Y.; François, M.L.M.; Colson, V.; Lanos, C.; Hussain, A.; Lawrence, M. Resistance to mold development assessment of bio-based building materials. Compos. B Eng. 2019, 158, 406-418. [CrossRef]

30. Ashour, T.; Georg, H.; Wu, W. Performance of straw bale wall: A case of study. Energy Build. 2011, 43, 1960-1967. [CrossRef]

31. Bainbridge, D.A. High performance low cost buildings of straw. Agric. Ecosyst. Environ. 1986, 16, $281-284$. [CrossRef]

32. Kumar, S.C.; Potnuru, A.; Varanasi, V.K.; Saha, P. Straw Bale as Sustainable Material. Int. J. Earth Sci. Eng. 2012, 5, 628-634.

33. Lamond, W.J.; Graham, R. The Relationship Between the Equilibrium Moisture Content of Grass Mixtures and the Temperature and Humidity of the Air. J. Agric. Eng. Res. 1993, 56, 327-335. [CrossRef]

34. Perry, R.H.; Green, D.W. Perry's Chemical Engineers' Handbook; McGraw Hill: New York, NY, USA, 1997.

35. Lawrence, M.; Heath, A.; Walker, P. Determining moisture levels in straw bale construction. Constr. Build. Mater. 2009, 23, 2763-2768. [CrossRef]

36. Goodhew, S.; Griffiths, R.; Woolley, T. An investigation of the moisture content in the walls of a straw-bale building. Build. Environ. 2004, 39, 1443-1451. [CrossRef]

37. Carfrae, J.; De Wilde, P.; Littlewood, J.; Goodhew, S.; Walker, P. Development of a cost effective probe for the long term monitoring of straw bale buildings. Build. Environ. 2011, 46, 156-164. [CrossRef]

38. Platt, S.; Walker, P.; Maskell, D.; Laborel-Préneron, A. Re-Baling Straw For Better Insulation. In Proceedings of the 3rd International Conference on Bio-Based Building Materials, Belfast, UK, 26-28 June 2019.

39. Ren, J.; Zhao, Z.; Zhang, J.; Wang, J.; Guo, S.; Sun, J. Study on the hygrothermal properties of a Chinese solar greenhouse with a straw block north wall. Energy Build. 2019, 193, 127-138. [CrossRef]

40. Rojas, C.; Cea, M.; Iriarte, A.; Valdés, G.; Navia, R.; Cárdenas-R, J.P. Thermal insulation materials based on agricultural residual wheat straw and corn husk biomass, for application in sustainable buildings. Sustain. Mater. Technol. 2019, 20, e00102. [CrossRef]

41. Nasser, R.; Radwan, M.A.; Sadek, M.A.; Elazab, H.A. Preparation of insulating material based on rice straw and inexpensive polymers for different roofs. Int. J. Eng. Technol. 2018, 7, 1989-1994. [CrossRef]

42. Costes, J.-P.; Evrard, A.; Biot, B.; Keutgen, G.; Daras, A.; Dubois, S.; Lebeau, F.; Courard, L. Thermal Conductivity of Straw Bales: Full Size Measurements Considering the Direction of the Heat Flow. Buildings 2017, 7, 11. [CrossRef]

43. Dubois, S.; Lebeau, F. Design, construction and validation of a guarded hot plate apparatus for thermal conductivity measurement of high thickness crop-based specimens. Mater. Struct. 2015, 48, 407-421. [CrossRef]

44. Conti, L.; Goli, G.; Monti, M.; Pellegrini, P.; Rossi, G.; Barbari, M. Simplified Method for the Characterization of Rectangular Straw Bales (RSB) Thermal Conductivity. In IOP Conference Series: Materials Science and Engineering; IOP Publishing: Bristol, UK, 2017; Volume 245, p. 052035.

45. Seitz, S.; MacDougall, C. Design of an Affordable Hot Box Testing Apparatus. In Proceedings of the NOCMAT 2015-Construction for Sustainability-Green Materials \& Technologies, Winnipeg, MB, Canada, 10-13 August 2015.

46. Gallegos-Ortega, R.; Magaña-Guzmán, T.; Reyes-López, J.A.; Romero-Hernández, M.S. Thermal behavior of a straw bale building from data obtained in situ. A case in Northwestern México. Build. Environ. 2017, 124, 336-341. [CrossRef] 
47. D'Alessandro, F.; Bianchi, F.; Baldinelli, G.; Rotili, A.; Schiavoni, S. Straw bale constructions: Laboratory, in field and numerical assessment of energy and environmental performance. J. Build. Eng. 2017, 11, 56-68. [CrossRef]

48. British Standards Institution (BSI). Thermal Performance of Building Materials and Products—Determination of Thermal Resistance by Means of Guarded Hot Plate and Heat Flow Meter Methods; BSI: London, UK, 2001.

49. Chaussinand, A. Straw Bale: An Innovative Sustainable Material in Construction. Key Eng. Mater. 2014, 632, 69-77. [CrossRef]

50. Wimmer, R. Wandsystem Aus Nachwachsenden Rohsthoffen Endbericht; Austria Center for Appropriate technology (GrAT): Vienna, Austria, 2001.

51. European committee for standardization (CEN). Thermal Performance of Buildings-Determination of Thermal Resistance by Hot Box Method Using Heat Flow Meter; CEN: Brussels, Belgium, 1998.

52. Jelle, B.P. Traditional, state-of-the-art and future thermal building insulation materials and solutions-Properties, requirements and possibilities. Energy Build. 2011, 43, 2549-2563. [CrossRef]

53. Seitz, S.; Beaudry, K.; MacDougall, C. Thermal Performance of Panels With High Density, Randomly Oriented Straw Bales. J. Green Build. 2018, 13, 31-55. [CrossRef]

54. Shea, A.; Wall, K.; Walker, P. Evaluation of the thermal performance of an innovative prefabricated natural plant fibre building system. Build. Serv. Eng. Res. Technol. 2013, 34, 369-380. [CrossRef]

55. Belhadj, B.; Bederina, M.; Makhloufi, Z.; Goullieux, A.; Quéneudec, M. Study of the thermal performances of an exterior wall of barley straw sand concrete in an arid environment. Energy Build. 2015, 87, 166-175. [CrossRef]

56. Deverell, R.; Goodhew, S.; Griffiths, R.; De Wilde, P. The noise insulation properties of non-food-crop walling for schools and colleges: A case study. J. Build. Apprais. 2009, 5, 29-40. [CrossRef]

57. European committee for standardization (CEN). Acoustic Measurements of Sound Insulation in Buildings and of Building Elements_Part 4: Field Measurements of Airborne Sound Insulation between Rooms; CEN: Brussels, Belgium, 1998.

58. HM Government. Approved Document E—Resistance to the Passage of Sound; RIBA Enterprises Ltd.: London, UK, 2003.

59. Decree of the Italian Prime Minister. Passive Acoustic Requirements of Buildings; Decree of the Italian Prime Minister: Rome, Italy, 1997.

60. UNI EN ISO 16283-3:2014. Acoustics-Field Measurement of Sound Insulation in Buildings and of Building Elements_Part 3: Façade Sound Insulation; Ente Italiano di Normazione: Milano, Italy, 2016.

61. UNI EN ISO 354:2003. Measurement of Sound Absorption in Reverberant Chamber; Ente Italiano di Normazione: Milano, Italy, 2003.

62. UNI EN ISO 12354-3:2017. Evaluation of the Acoustic Performance of Buildings from the Performance of the Products-Part 3: Sound Insulation from the Noise Coming from Outside by Air; Ente Italiano di Normazione: Milano, Italy, 2017.

63. Bernard, T.; Azra, K.; Bednar, T. Bautechnische, ökologische und ökonomische Grundlagen der Planung von Strohballen-Gebäuden-Literaturzusammenstellung und Analyse des thermischen Leitwertes der Gebäudehülle. Bauphysik 2014, 36, 134-143. [CrossRef]

(C) 2019 by the authors. Licensee MDPI, Basel, Switzerland. This article is an open access article distributed under the terms and conditions of the Creative Commons Attribution (CC BY) license (http://creativecommons.org/licenses/by/4.0/). 